\title{
Participatory and Motivating Methods for Empowerement to Teacher in Implementing Thematic Learning Method
}

\author{
Siti Johariyah \\ State Islamic University 'Sunan Kalijaga' Yogyakarta
}

\begin{abstract}
The way of looking at something in the present era is different from the past era. In the past era, something is looked at partially. The effect of this situation is harm for the life. At present era and the future, look at something should comprehensively and integral. The profile of human beings who are able to think comprehensively and integral may be designed by thematic learning method. Thematic learning method is an interesting issue to be studied. This research is focused in thematic learning method. This research is community based research, that is a research that based on empowerment activity. So there are two main activities, they are research and empowerment. The implementation both programs are together. During the empowerment program, there is a research (collecting data). Experts said that in community based research, there is an action research, so there is a categorization that community based research is include action research. The result of the research showed that empowerment to teachers in implementing thematic learning is not significant. The trend of competence is $0.152+0.716$ Motivation (Competence $=0.152+0.716$ Motivation). It can be explained that "Each increasing of 1 point of motivation can increases 0.716 of competence.
\end{abstract}

Keywords: Empowerment, Thematic learning

\section{Introduction}

The way of looking at something in the present era is different from the past era. In the past era, something is looked at partially. The effect of this situation is harm for the life. At present era and the future, look at something should comprehensively and integral. The question is why? Looking at something comprehensively and integral have some values in life such like not egoist, not discriminative, cooperation, and so on. Why this phenomenon is important to be revealed? What is the relationship with education?. It is important to study this phenomenon because nowadays human being, especially in Indonesia is still think partially not integral. It is as a result of education done of course. Education sector must responsible to this situation. The condition of character of human being is education's responsibility.

When we are talking about education, we discuss about learning process in it. Learning process which is able to build students think comprehensively and integral is thematic learning method. Thematic learning method is a method which is present the learning process using themes and sub themes.

Thematic learning method at school in Indonesia was already launched together with curriculum 2013 policy. Schools in Indonesia were recommended to implement thematic learning method specially at elementary school. It is good policy, although most of the education people don't know its philosophy. Not only the philosophy, the way to implement it is also still as a problem.

Indonesian teacher are not prepared to implement thematic learning method. At some universities and higher education don't apply thematic situation. Some of faculty of education at some universities also don't implement it. Most of faculty of education present thematic learning method as a subject matter, otherwise they don't implement it in their real daily life. Some faculty of education at universities don't design thematic learning situation yet. As an effect of the condition explained above, students of faculty of education are not ready yet to implement thematic learning method.

This phenomenon can be interesting issue to be studied. This research is focused in thematic learning method. This research is community based research, that is a research that based on empowerment activity. So there are two main activities, they are research and empowerment. The implementation both programs are together. During the empowerment program, there is a research (collecting data). Experts said that in community based research, there is an action research, so there is a categorization that community based research is include action research.

What kind of action was done in this research? Action that was done is empowerment to teachers in research location. There are two questions of the research, they are (1) what is the target of the empowerment?, and (2) what is the method of the empowerment?. The answer of first question is "skill of teacher in implementing thematic learning will be improved". The answer of second question is "motivation and participatory method. Mengapa metode motivatif dan participatorif? 
According Istiningsih (2008), in learning process, it should pay attention to students' condition. There are four classification of students' condition, namely (1) high motivation and competence, (2) high motivation, low competence, (3) low motivation, high competence, and (4) low motivation and competence. For motivating issue, the empowerment that may be applied is motivation method. For competence issue, the empowerment that may be applied is participative method. Based on the above explanation, it can be explained detail that motivating method is suitable for the clients (read: teachers) who have low motivation, and participative method is suitable for the clients who have low skill in implementing thematic learning. The empowerment program in this research is an empowerment for the teacher of Islamic Basic School in implementing thematic learning method. The focus of the study is motivating and participatory method.

The research will describe: (1) the condition of teacher's motivation (before and after empowerment) in implementing thematic learning method; (2) the method of empowerment namely motivating and participatory method. Motivating method is applied for the teachers who have low motivation in implementing thematic learning method, and participatory method is applied for the teachers who have low skill in implementing thematic learning skill. The empowerment to the teachers is hoped may enrich motivation and skill of teacher in implementing thematic learning method. If the result of empowerment is not significant, so the research will be continued to find out the factors that may influence it.

Teacher has a great role in guaranting the success of education. So teacher's competence is a core of empowerment of education in general, and specially empowerment to teacher. Considering that thematic learning method is very important in improving quality of education, so program of community service for higher education that takes a theme teacher's empowerment through enriching competence in applying learning strategy, specially in implementing thematic learning method is an urgent program.

Thematic learning is a method that uses theme in presenting object study. There are integration and interconnection values in it. The integration and interconnection happens for six subject matters namely social science, Indonesian language, mathematics, civics, natural science, and religion. They are only six subjects matters because the learning process happens at Islamic elementary school. May be for non religious school, there are only five subject matters.

Motivating method is the method to enrich motivation of teacher. There are some techniques to motivate teachers. Actually, there is correlation between motivation and need. This research does not study about need as moderator or linkage variable. The reason why need is not necessary to be studied, because thematic learning method is as a policy that must be applied by teachers. It is not necessary to know the teacher's need of implementing thematic learning.

Participatory method is a learning method that .... participants (read: teacher). According Ki Hadjar Dewantara, there is a technique in asking teachers to participate in programs (seminar, workshop, socialization) namely Tut Wuri (Javanese). Tut Wuri is broken down in to three ways namely Ing Ngarso Sung Tulodho, Ing Madyo Mangun Karso, and Tut Wuri Handayani. Ing Ngarso Sung Tulodho is applied for teachers who are low competence, Ing Madyo Mangun Karso is applied for teachers who are fairly competence, and Tut Wuri Handayani is applied for teachers who are high competence.

\section{AIM}

To increase the motivation and competence of teachers in implementing thematic learning method through participatory and motivating approaches.

\section{Method}

The research is classified as a community based research. There are two main activities, they are: (1) empowerement, and (2) research. The empowerement was done with various activities such like seminar, training and workshop. The research was done by collecting data, and data analysis. Two kinds of activieties were done integrated not separated. It means that while doing empowering, also doing research. The community whom the empowerement done was teachers of Madrasah Ibtidaiyah (Arabic) at one district in Sleman regency Yogyakarta province.

The datas were collected from ten teachers. There were ten teachers were empowered by the researcher. The instrument for collecting data is guideliness for observation. There are three items for motivation and ten items for competence. The datas were taken six times. The first time was before empowerment. The second data until the sixth datas were taken about everyweek or after the empowerment activities. There are four points in the guideliness, they are 1,2,3 and 4. The condition of the teachers (motivation and competence) are categorized in to three, they are low with the score 1-2, moderate with the score 2.1 - 3, and high with the score 3.1 - 4. The datas were analyzed with regression. 


\section{Result And Analysis}

This type of reseach is community based research. This study was performed by an action (as the form of an empowerment) to the community in this case is teachers. The actions were trainings and seminars. While doing action, it were also done observation to the teacher's motivation and competence to implement thematic learning method. The datas of motivation in implementing thematic learning method and the ability to implement thematic learning method as follows.

The motivation of teachers in implementing thematic learning method

Based on data collection, the motivation of the teachers in implementing thematic learning method as follows.

Table 1. The Motivation of The Teachers in Implementing

Thematic Learning Method

\begin{tabular}{|c|c|c|c|c|c|}
\hline Observation & Observation & Observation & Observation & Observation & Observation \\
\hline $\mathbf{1}$ & $\mathbf{2}$ & $\mathbf{3}$ & $\mathbf{4}$ & $\mathbf{5}$ & $\mathbf{6}$ \\
\hline 2.15 & 2.31 & 2.35 & 2.47 & 2.64 & 2.92 \\
\hline
\end{tabular}

The trend of the teacher's motivation can be presented in chart 1, as follows: The first observation means that the motivation of the teachers before the empowerement was done. The score of the first observation is 2.15 (based on the categorization: score $1-2$ is low, $2.1-3$ is moderate, and $3.1-4$ is high level), it is categorized in moderate condition. Teachers have the motivation to implement thematic learning method but the conditions are likely in the lower position.

After the seminar with the theme "Understanding Thematic Learning", then the motivation of teachers increases in position 2.31, it is still in moderate condition. The third observation is 2.35 . This increase occurred due to treatment through a seminar on "Benefit of Thematic Learning". Through the seminar on "Requirements of Teachers in Implementing Thematic Learning", then the motivation of teachers increased to 2.47 (the fourth observation). At the fifth obeservation, the motivation's score is 2.64 and the sixth is 2.92 . The action taken to improve the teacher's motivation were seminar on "Basic Reason of Implementing Thematic Learning" and "Relationship between Thematic Learning and Post Modern Era".

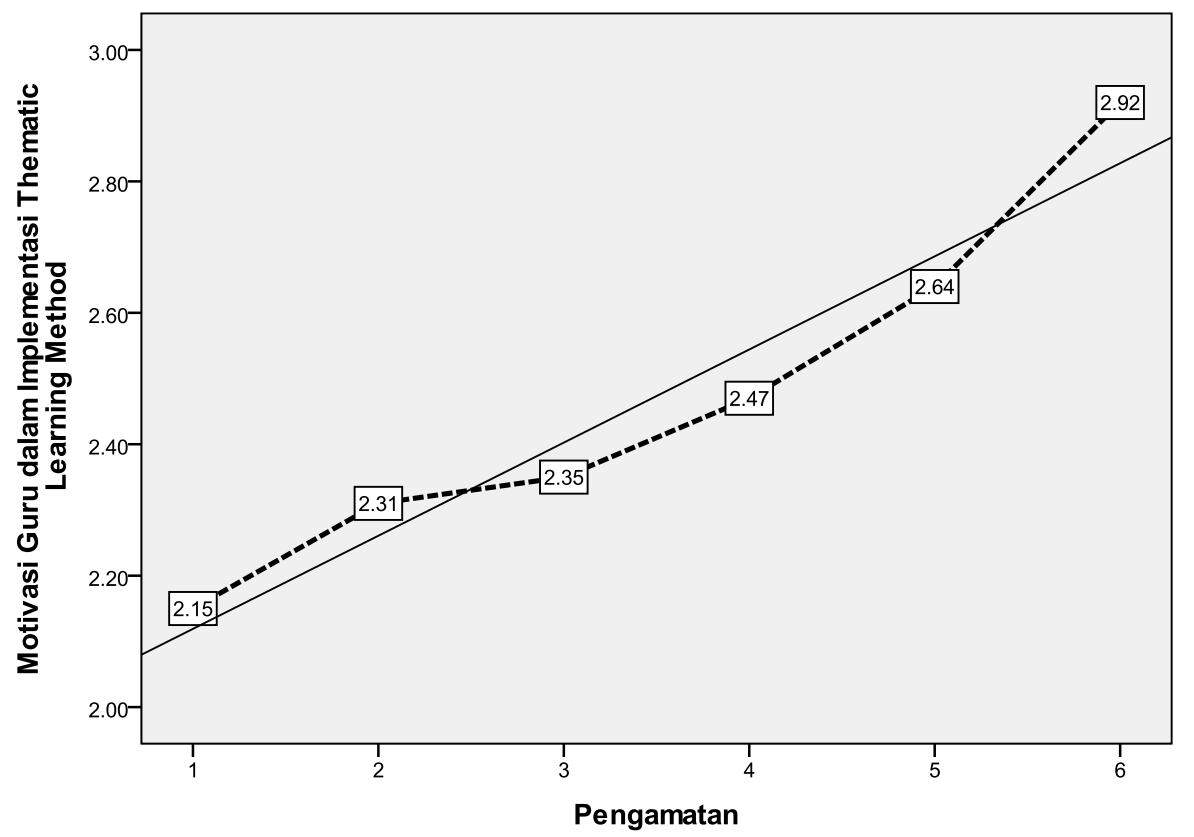

Chart 1. The Trend of Teacher's Motivation in Implementing

Thematic Learning Method

Based on the chart above, it can be explained that the empowerement program is able to increase the motivation of the teachers although not so significant. The increasing was happened 0.77 . The highest increase when the score increased three (3) points. So it can be said that the increasing is low. The most strong factor assumed as a constraint in increasing the motivation is the "lack of confidence" of teachers. They do not believe that in fact they were able to implement thematic learning method. The training on "CONFIDENCE" is needed for them.

\section{The competence of teachers in implementing thematic learning method}

Based on data collection, the competence of the teachers in implementing thematic learning method as follows. 
Participatory and Motivating Methods for Empowerement to Teacher in Implementing Thematic ..

Table 2. The Competence of The Teachers in Implementing Thematic Learning Method

\begin{tabular}{|c|c|c|c|c|c|}
\hline Observation 1 & Observation 2 & Observation 3 & Observation 4 & Observation 5 & Observation 6 \\
\hline 1.66 & 1.77 & 1.85 & 1.97 & 2.10 & 2.19 \\
\hline
\end{tabular}

The trend of the teacher's competence can be presented in chart 1, as follows: The first observation means that the competence of the teachers before the empowerement was done. The score of the first observation is 1.66 (based on the categorization: score $1-2$ is low, $2.1-3$ is moderate, and $3.1-4$ is high level), it is categorized in low condition. Teachers have the competence to implement thematic learning method but the conditions are in the low position.

After the training with the theme "Designing Learning Output", then the competence of teachers increased in position 1.77, it is still in low condition. The third observation is 1.85. This increase occurred due to treatment through a seminar on "Designing Theme and Sub-Theme". Through the seminar on "Integration of Five Basic Subjects at Elementary School", then the competence of teachers increased to 2.10 (the fourth observation). At the fifth observation, the competence's score is 2.10 and the sixth is 2.19 . The actions taken to improve the teacher's competence were seminar on "Designing Learning Media" and "Shifting of Learning Paradigm".

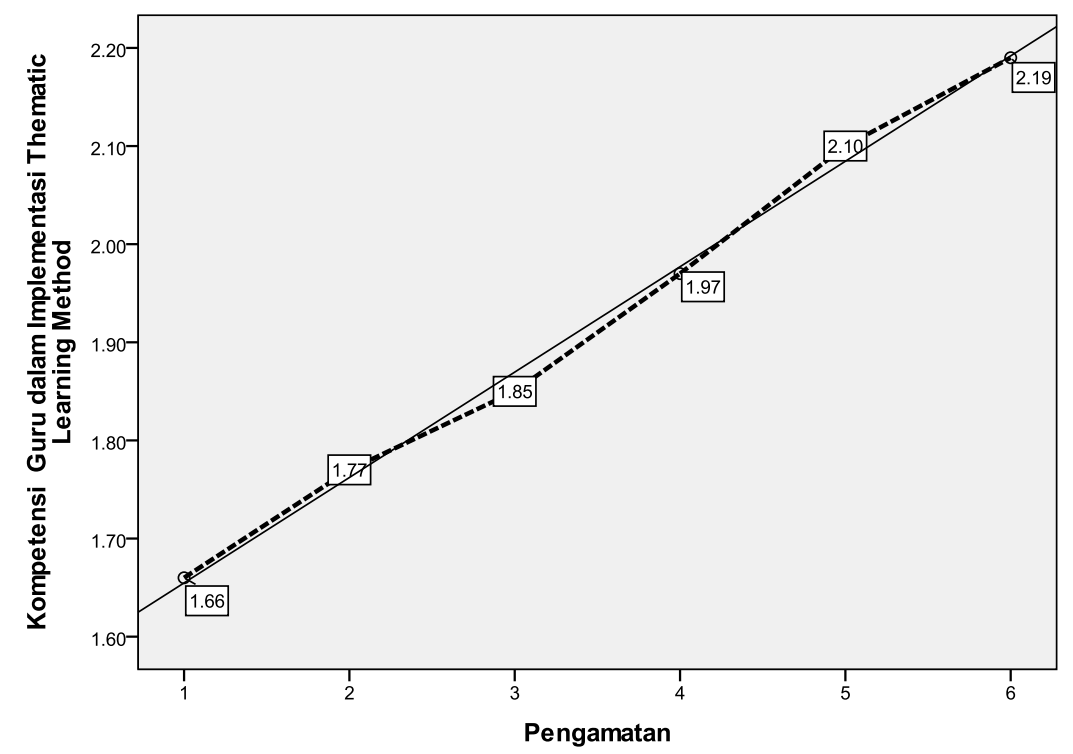

Chart 1. The Trend of Teacher's Competence in Implementing Thematic Learning Method

Based on the chart above, it can be explained that the empowerement program is able to increase the competence of the teachers although not so significant. The increasing was happened 0.77 . The highest increase when the score increased three (3) points. So it can be said that the increasing is low. The most strong factor assumed as a constraint in increasing the motivation is the "lack of confidence" of teachers. They do not believe that in fact they were able to implement thematic learning method. The training on "CONFIDENCE" is needed for them.

Based on the chart above, it can be explained that the empowerment program is able to increase the competence of the teachers although not so significant. The increasing was happened 0.53 . The highest increase when the score increased three (3) points. So it can be said that the increasing is low. The most strong factor assumed as a constraint in increasing the competence is "designing the learning media" of teachers. They do not want to design media because according them, it needs time, energy, also finance. So it is needed to facilitate the teachers in preparing learning media. The concrete form in facilitating them for planning the media such as training about learning media specially media using computer; alocate funds for buying equipment of learning media.

The Influence of motivation on the competence of teachers in implementing thematic learning method.

Based on data analysis, it can be desribed as follows: The trend of competence is $0.152+0.716$ Motivation (Competence $=0.152+0.716$ Motivation). It can be explained that "Each increasing of 1 point of motivation can increases 0.716 of competence". The teachers retain competence although the motivation is dispensed (motivation $=0$ ), as big as 0.152 . Below is a chart of relationship between motivation and competence of teachers in implementing thematic learning. 


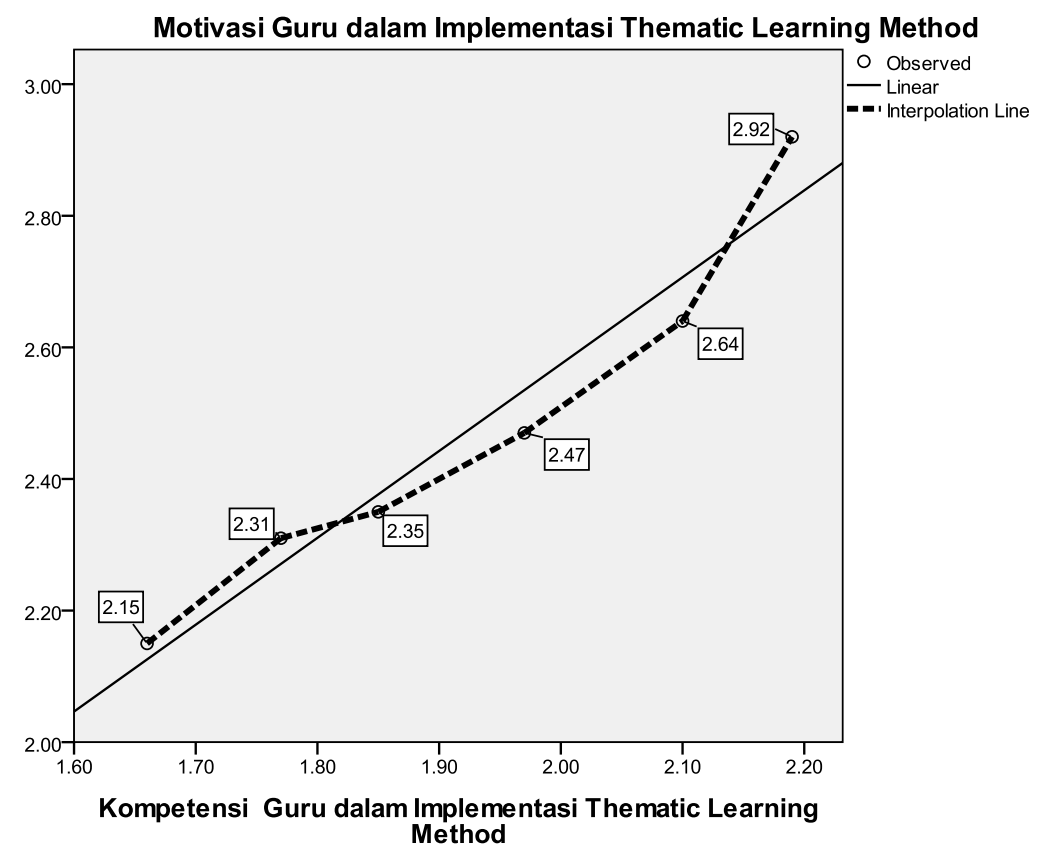

Chart 3. Relationship between Motivation and Competence of teachers in Implementing Thematic Learning

It can be explained that even if teachers do not have the motivation in implementing thematic learning, but the teacher has the competence of implementing thematic learning as big as 0.152 . When the motivation is increase as big as 1 point, so the competence will increase as big as 0.176 . It means that the influence of motivation is not significant to the competence of teachers in implementing thematic learning method.

Based on the data analysis it can be explained that both motivation and competence of the teachers in implementing thematic learning are very important to be paid attention. The motivation is easier to be increased comparing with the competence. So it is important to increase the competence regularly. It is suggested that each month, the training of thematic learning done twice for example.

Factors that influence the motivation and competence of teachers in implementing thematic learning method.

\section{Factors influence the teacher's motivation}

The datas were taken with in depth interview to headmaster and teachers. They explained that (1) they don't not believe about their ability to implement thematic learning method because until now (read before the empowerment), they never get training on thematic learning method; (2) They (teacher) are nervous with thematic learning method; (3) They assumed that thematic learning is a complicated method; (4) They still asked what kind of skills that must be mastered by teachers in implementing thematic learning method.

When it was examined deeply, it can be found that most of teachers are nervous. In turn later this nervous will weaken the motivation of teachers in implementing thematic learning method. Until now, motivation of teachers in implementing thematic learning method is still low. So the effort of headmaster, Education officers, and Ministry of Education and Culture in Indonesia are still needed in motivating teachers in implementing thematic learning method. The efforts that can be done such like: socialization of thematic learning method, seminar on "urgency of thematic learning method", workshop on motivation building of teachers in implementing thematic learning method, and similar seminars, trainings and workshops.

\section{Factors influence the teacher's competence}

Factors influence teacher's competence in implementing thematic learning method are (1) ability in studying curriculum, (2) ability in designing learning media, (3) ability in designing to implementing learning assessment. Ability in studying curriculum is teacher's ability in presenting learning objects or learning problems. Ability in designing learning media is ability to design until implementing learning media based on information technology and non information technology, media by design and by utilization. Ability in designing until implementing learning assessment is ability in making instruments of assessment until implementing learning assessment that are appropriate with learning output targeted.

This research finds teachers' competence that must be belonging by teachers in implementing thematic learning method or it can be said as requirement of teachers in implementing thematic learning method as follows: (1) 
competence in connecting a science with others; (2) competence in designing until implementing audio visual learning. Other supporting competences are : (1) mastering students with their uniqueness, (2) mastering in studying curriculum, (3) mastering the assessment. The main competence is ability in designing themes which are appropriate with cognitive and psychomotor of students.

For higher education, especially faculty of education, thematic learning method is not only as subject matter given to students in theory but it must be implemented in real life, in daily life, in each activity. In turn, future teachers will have confidence and they will also apply at schools.

\section{Discussion}

The research was done in Indonesia, so the situation is happened in Indonesia and some recommendation given above are suitable for Indonesian education. Thematic learning method is suitable for building the students in thinking comprehensively. Post modern era needs human being who are able to think comprehensively. Otherwise, think partially and separated or ego sector will harm.

It is a task of higher education, especially faculty of education to design the situation at campus or implementing thematic learning condition, in order, in turn they (students) will be able to implement it at their school. If they implement it, in turn students will be are able to think comprehensively, not egoist human being, able to live together with others. It can be concluded that thematic learning can build characters of students.

Nowadays, character is as a problem in Indonesia, some criminals, amoral happens in Indonesia. It is a an effect of education. Education sector must responsible with this situation. Education here is the environment. Like Djohar (2016) said that education is the condition, so things that must be considered is the condition of environment must be good. It is like what Ki Hadjar Dewantara's (father founding of Indonesian education) thought "three center of education", namely family environments, schools environment, and society environment. The education happens in three environment and it must be balanced and connected each other.

Thematic learning will answer and solve character problem. The research finds an hypothesis, "Characters that may be built through thematic learning are: cooperation, think comprehensively, not egoist, care, and believe to God". For Indonesian, believe to God is as an aim of education because the first national principle is God almighty.

Because there is a relationship between thematic learning and character, so education in Indonesia should implement thematic learning method. Thematic learning method is one of the way to solve character problem in Indonesia. The revolution to build skill of teacher in implementing thematic learning is urgent to be done. Besides of skill, it is also necessary to build the teacher's motivation to implement it. The skill of teacher in implementing thematic learning can be improve by participatory method, and the motivation to implement it can be enriched by motivation method. The techniques to realize both methods are seminar, workshop, and group discussion with the materials about thematic learning method such as philosophy, paradigm, concept, mechanism, and positive points of thematic learning method. Because the techniques to implement motivation and participatory methods are same, so one program may have to aims, for example a seminar on thematic learning may have two aims namely enriching motivation and skill in implementing thematic learning.

\section{References}

[1]. Britha Mikkelsen, Metode Penelitian Partisipatoris Dan Upaya Pemberdayaan Panduan Bagi Praktisi Lapangan, (Jakarta: Yayasan Obor Indonesia, 2003).

[2]. Djohar \& Istiningsih. Filsafat Ki Hadjar Dewantara dalam Kehidupan Nyata. Dalam Proses

[3]. Fredian Tonny Nasdian, Pengembangan Masyarakat, (Jakarta: Yayasan Pustaka Obor Indonesia, 2015).

[4]. Hamruni \& Istiningsih. 2016. Thematic Learning is A Tool In Improving Education in Indonesia. IOSR - JRME. Vol ... Issue ....

[5]. Herman Hidayat (Ed), Pengelolaan Hutan Lestari: Partisipasi, Kolabrasi Dan Konflik, (Jakarta: Yaysan Pustaka Obor Indonesia, 2015).

[6]. Istiningsih. 2015. Teacher's Professional Education and Educational Clinic. New York. POD Limited

[7]. Kieffer C.H. (1984). Citizen Empowermwent: A Developmental Perspective. Prevention In Human Iservice, Vol , USA

[8]. Pearsons, Ruth J, dkk. (1994). The Integration of Social Work Practice. California: Book Cole.

[9]. Subroto, T.W. 2012. Analisis Pengaruh Pemberdayaan Guru terhadap Kinerjanya dalam Meningkatkan Kualitas Pendidikan di Sekolah Dasar di Kota Surabaya. Teori dan Penelitian Pendidikan Dasar, (Online), 1 (1): 1-18.

[10]. Suharto, Edi. (2005). Membangun Masyarakat Memberdayakan Rakyat; Kajian Strategis Pembangunan Kesejahteraan Sosial dan Pekerjaan Sosial. Bandung : PT Refika Aditama.

[11]. Suharto, Edi. (1987). Pembangunan, Kebijakan Sosial dan Pekerjaaan Sosial: Spektrum Pemikiran. Bandung : Lembaga Studi Pembangunan STKS.

[12]. Sulthon.(2009). Membangun Semangat Kerja Guru. Yogyakarta: LaksBang Pressindo.

[13]. Swift, c. (1987). Empowerment: An Emerging Mental health Technology; Journasl of Primary Prevention, USA.

[14]. Zulkarnain Nasutio, Solidaritas Sosial Dan Partisipasi Masyaraakat Desa Transisi: Suatu Tinjauan Sosial, (Malang: UMM Press, 2009).

[15]. Sardiman A.M, Interaksi \& Motivasi Belajar Mengajar, Jakarta: PT Rajagrafindo Persada, 2011, hlm 73-83 